\title{
An Integrated Model for the Design of Agile Supply Chains
}

\author{
Professor Martin Christopher \\ Cranfield Centre for Logistics \& Transportation \\ School of Management, Cranfield University
}

\section{Professor Denis Towill}

Logistics Systems Dynamics Group

Cardiff University

\section{Summary}

The latter part of the $20^{\text {th }}$ Century saw the lean production paradigm positively impact many market sectors ranging from automotive through to construction. In particular there is much evidence to suggest that level scheduling combined with the elimination of muda has successfully delivered a wide range of products to those markets where cost is the primary order winning criteria. However, there are many other markets where the order winner is availability. This has led to the emergence of the agile paradigm typified by 'quick response' and similar initiatives. Nevertheless, 'lean' and 'agile' are not mutually exclusive paradigms and may be married to advantage in a number of different ways. This paper explores ways in which hybrid strategies can be developed to create cost-effective supply chains and proposes an integrated manufacture/logistics model for enabling the essential infrastructure.

\section{Introduction}

A key feature of present day business is the idea that it is supply chains that compete, not companies (Christopher, 1992), and the success or failure of supply chains is ultimately determined in the marketplace by the end consumer. Getting the right product, at the right price, at the right time to the consumer is not only the lynch pin to competitive success but also the key to survival. Hence, customer satisfaction and marketplace understanding are crucial elements for consideration when attempting to establish a new supply chain strategy. Only when the requirements and constraints of the marketplace are understood can an enterprise attempt to develop a strategy that will meet the needs of both the supply chain and the end customer.

Supply chain performance improvement initiatives strive to match supply to demand thereby driving down costs simultaneously with improving customer satisfaction. This invariably requires uncertainty within the supply chain to be reduced as much as 
practicable so as to facilitate a more predictable upstream demand (Mason-Jones et al., 1999). Sometimes however, uncertainty is impossible to remove from the supply chain due to the type of product involved. For example, if a product is highly fashionable then by its intrinsic nature its demand will be unpredictable. Hence, specific supply chains are faced with the situation where they have to accept uncertainty but need to develop a strategy that enables them to still match supply and demand.

Significant interest has been shown in recent years in the idea of 'lean manufacturing' (Womack, Jones \& Roos, 1990), and the wider concepts of the 'lean enterprise' (Womack, \& Jones, 1996). The focus of the lean approach has essentially been on the elimination of waste or muda. The upsurge of interest in lean manufacturing can be traced to the Toyota Production Systems (TPS) with its focus on the reduction and elimination of waste (Ohno, 1988). However, the origins of lean manufacture are certainly visible in Spitfire aircraft production in the UK in World War II, and Keiretsu dates back to the US automotive industry in 1915 (Towill, et al., 2000). In the context of the present paper, it has been argued elsewhere (Christopher, 2000) that lean concepts work well where demand is relatively stable and hence predictable and where variety is low. Conversely, in those contexts where demand is volatile and the customer requirement for variety is high, a much higher level of agility is required.

Agility is a business-wide capability that embraces organisational structures, information systems, logistics processes and in particular, mindsets. A key characteristic of an agile organisation is flexibility. In that respect, the origins of agility as a business concept lie partially in flexible manufacturing systems (FMS). Initially it was thought that the route to manufacturing flexibility was through automation to enable rapid changeovers (i.e. reduced set-up times) and thus enable a greater responsiveness to changes in product mix or volume. Later this idea of manufacturing flexibility was extended into the wider business context (Nagel and Dove, 1991) and the concept of agility as an organisational orientation was born.

Naylor et al. (1999) provide a useful definition of the two paradigms we are considering as follows: 
"Agility means using market knowledge and a virtual corporation to exploit profitable opportunities in a volatile marketplace."

"Leanness means developing a value stream to eliminate all waste including time, and to enable a level schedule."

It is the purpose of the present paper to show the various ways in which these paradigms may be combined to enable highly competitive supply chains capable of winning in a volatile and cost-conscious environment. In doing so we shall emphasise the important differences between the two paradigms, and also how one may benefit from the implementation of the other. As Warnecke and Huser (1995) forcefully point out, there is a need in all change management programmes to consider the intellectual as well as the operational needs of the supply chain. Hence, the development and description of our Integrated Model for enabling the agile enterprise based upon the concept of a seamless connection between manufacture and logistics.

\section{The Cyclical Nature of Market Winners and Market Qualifiers}

Hill (1993) has earlier developed the concept of 'order qualifiers' and 'order winners' against which it is advocated that manufacturing strategy should be determined. As these labels suggest, it is important for every business to understand what the baseline is for entering into a competitive arena - these are the 'order qualifiers'. To actually win the order requires specific capabilities and these Hill termed the 'order winners'. The definition of order qualifiers and order winners then logically leads to the specification of the appropriate manufacturing strategy. We can borrow from these important ideas to develop a wider supply chain oriented concept of 'market qualifiers' and 'market winners'. The notion here is that to be truly competitive requires not just the appropriate manufacturing strategy, but rather an appropriate holistic supply chain strategy.

The connection between these ideas of 'qualifiers' and 'winners' and 'lean' and 'agile' is critical. At its simplest the lean paradigm is most powerful when the winning criteria is cost; however, when service and customer value enhancement are prime requirements for market winning then the likelihood is that agility will become the critical dimension. Figure 1 illustrates the crucial differences in focus between the 
lean and agile paradigm depending upon the market qualifiers and the market winners based upon the work of Mason-Jones et. al. (2000).

\begin{tabular}{|c|c|c|}
\hline $\begin{array}{l}\text { Agile } \\
\text { Supply }\end{array}$ & $\begin{array}{l}\text { 1. Quality } \\
\text { 2. Cost } \\
\text { 3. Lead Time }\end{array}$ & 1. Service Level \\
\hline \multirow[t]{2}{*}{$\begin{array}{l}\text { Lean } \\
\text { Supply }\end{array}$} & $\begin{array}{l}\text { 1. Quality } \\
\text { 2. Lead Time } \\
\text { 3. Service Level }\end{array}$ & 1. $\underline{\text { Cost }}$ \\
\hline & $\begin{array}{c}\text { Market } \\
\text { Qualifiers }\end{array}$ & $\begin{array}{l}\text { Market } \\
\text { Winners }\end{array}$ \\
\hline נו & Fig 1 & \\
\hline
\end{tabular}

It is in the nature of competition that last year's market winner will be replaced this year by a former market qualifier (Johannson et. al., 1993). This can be illustrated in the context of the lean and agile paradigms by studying the migration of the operation of the Personal Computer supply chain. Thus Table I describes the transition over a 15-20 year period from product driven to market orientated to market driven and finally through to individual customer driven enterprise (Christopher and Towill, 2000). During that change the market winner has rotated between quality, cost, availability and lead-time. But at any one point in time the other performance metrics remain market qualifiers which cannot be prejudiced if business is to continue to be won.

\section{Attributes of Lean and Agile Supply}

Whereas quality, service level, and lead-time are market qualifiers for lean supply, with the market winner then being cost, the latter benchmark is merely an important qualifier in agile supply (Christopher and Towill, 2000). Fisher (1997) makes a similar point which is that where the risk of obsolescence and/or the cost of a stock-out is high relative to the cost of production and distribution, then a different supply chain solution is required. This leads to the conclusion that the total costs for the Product Delivery Process (PDP) are :- 


\section{Supply Chain Total PDP Costs $=$ Physical PDP Costs + Marketability Costs}

Where

- Physical Costs includes all production, distribution, and storage costs.

- Marketability Costs includes all obsolescence and stockout costs.

\begin{tabular}{|c|c|c|c|c|}
\hline $\begin{array}{l}\text { SUPPLY CHAIN } \\
\text { EVOLUTION } \\
\text { PHASE }\end{array}$ & I & II & III & IV \\
\hline $\begin{array}{l}\text { SUPPLY CHAIN } \\
\text { TIME } \\
\text { MARKER }\end{array}$ & early 1980s & late $1980 \mathrm{~s}$ & early 1990s & late 1990s \\
\hline $\begin{array}{l}\text { SUPPLY CHAIN } \\
\text { PHILOSOPHY }\end{array}$ & $\begin{array}{l}\text { Product } \\
\text { Driven }\end{array}$ & $\begin{array}{l}\text { Market } \\
\text { Orientated }\end{array}$ & $\begin{array}{l}\text { Market } \\
\text { Driven }\end{array}$ & $\begin{array}{l}\text { Customer } \\
\text { Driven }\end{array}$ \\
\hline $\begin{array}{l}\text { SC } \\
\text { TYPE }\end{array}$ & \begin{tabular}{|l} 
Lean \\
Functional \\
Silos \\
\end{tabular} & $\begin{array}{l}\text { Lean } \\
\text { Supply } \\
\text { Chain } \\
\end{array}$ & $\begin{array}{l}\text { Leagile } \\
\text { Supply } \\
\text { Chain } \\
\end{array}$ & \begin{tabular}{|l|} 
Customised \\
Leagile \\
Supply Chain \\
\end{tabular} \\
\hline $\begin{array}{l}\text { MARKET } \\
\text { WINNER }\end{array}$ & Quality & Cost & Availability & Lead Time \\
\hline $\begin{array}{l}\text { MARKET } \\
\text { QUALIFIERS }\end{array}$ & $\begin{array}{l}\text { (a) Cost } \\
\text { (b) Availability } \\
\text { (c) Lead Time } \\
\end{array}$ & $\begin{array}{l}\text { (a) Availability } \\
\text { (b) Lead Time } \\
\text { (c) Quality }\end{array}$ & $\begin{array}{l}\text { (a) Lead Time } \\
\text { (b) Quality } \\
\text { (c) Cost } \\
\end{array}$ & $\begin{array}{l}\text { (a) Quality } \\
\text { (b) Cost } \\
\text { (c) Availability } \\
\end{array}$ \\
\hline $\begin{array}{l}\text { PERFORMANCE } \\
\text { METRICS }\end{array}$ & $\begin{array}{l}\text { (a) Stock Turns } \\
\text { (b) Production } \\
\text { Cost }\end{array}$ & $\begin{array}{l}\text { (a) Throughput } \\
\text { Time } \\
\text { (b) Physical } \\
\text { Cost }\end{array}$ & $\begin{array}{l}\text { (a) Market Share } \\
\text { (b) Total Cost }\end{array}$ & $\begin{array}{l}\text { (a) Customer } \\
\text { Satisfaction } \\
\text { (b) Value Added }\end{array}$ \\
\hline
\end{tabular}

Table I

Summary of the Transition in the Personal Computer supply Chain from Product Driven to Customer Driven Operations

[Christopher and Towill, 2000]

The first cost source (PDP) dominates lean supply whereas the second cost source (marketability costs) dominates agile supply. Note that lost sales are gone forever in the agile supply chain whether the cause is due to stockouts or to obsolescence. This is because it is an extremely harsh and competitive marketplace with little brand loyalty. As we shall see later, the requirement is for the product to be both affordable and available. We shall now undertake a detailed comparison of lean and agile supply by comparing specific attributes which highlight the specific problems to be overcome in enabling the appropriate business strategy to be adopted.

Both agility and leanness demand high levels of product quality. They also require minimisation of total lead-times defined as the time taken from a customer raising a 
request for a product or service until it is delivered. Total lead-time has to be minimised to enable agility, as demand is highly volatile and thus difficult to forecast. If a supply chain has long end-to-end lead-time then it will not be able to respond quickly enough to exploit marketplace demand. Furthermore effective engineering of cycle time reduction always leads to significant bottom line improvements in manufacturing costs and productivity Towill (1996).

Lead-time needs to be reduced in lean manufacturing as by definition excess time is waste and leanness calls for the elimination of all waste. The essence of the difference between leanness and agility in terms of the total value provided to the customer is that service level (availability) is the critical factor calling for agility whilst cost, and hence the sales price, is clearly linked to leanness. However, whereas the Total Cycle Time Compression Paradigm (Towill, 1996), when effectively implemented, is a sufficient condition for achieving lean production, it is only one necessary condition for enabling agile supply.

\begin{tabular}{|l|l|l|}
\hline $\begin{array}{l}\text { DISTINGUISHING } \\
\text { ATTRIBUTES }\end{array}$ & LEAN SUPPLY & AGILE SUPPLY \\
\hline Typical Products & Commodities & Fashion Goods \\
\hline Marketplace Demand & Predictable & Volatile \\
\hline Product Variety & Low & High \\
\hline Product Life Cycle & Long & Short \\
\hline Customer Drivers & Cost & Availability \\
\hline Profit Margin & Low & High \\
\hline Dominant Costs & Physical Costs & Marketability Costs \\
\hline Stockout Penalties & Long Term Contractual & Immediate and Volatile \\
\hline Purchasing Policy & Buy Materials & Assign Capacity \\
\hline Information Enrichment & Highly Desirable & Obligatory \\
\hline Forecasting Mechanism & Algorithmic & Consultative \\
\hline
\end{tabular}




\section{Comparison of Lean Supply with Agile Supply : The Distinguishing Attributes} [Source: Mason-Jones, Naylor and Towill (2000)]

Table II illustrates the comparison of attributes between lean and agile supply. In the volatile unpredictable marketplace for "fashion" goods, both stockout and obsolescence costs are punitive. Consequently the purchasing policy moves from placing orders upstream for products moving in a regular flow to that of assigning capacity to finalise products in rapid response mode. As Fisher et al (1994) have indicated this means forecasting via "intelligent" consultation so as to maximise inputs from "rich" marketplace insider sources.

\section{Practical Ways of Marrying the Lean and Agile Paradigms}

As we have indicated, there are a number of common elements between the lean and agile paradigms. Provided the whole concept is fully thought through and properly managed, lean and agile businesses can co-exist, even when on the same site and with some limited rotation of personnel (Aitken, 2001). Here are three proven ways in which the paradigms have been brought together to provide available and affordable products for the end customer.

\section{The Pareto Curve Approach}

Many companies manufacturing or distributing a range of products will find that the Pareto Law will apply and can be exploited to determine supply strategy. Typically an analysis of the business will show that the 80/20 (or similar) rule holds (Koch, 1997). In other words, $80 \%$ of total volume will be generated from just $20 \%$ of the total product line. The way in which these $20 \%$ are managed should probably be quite different from the way the remaining $80 \%$ are managed. For example it could be argued that the top $20 \%$ of products by volume are likely to be more predictable and hence they lend themselves to lean principles of manufacturing and distribution. The slow moving $80 \%$ on the other hand will typically be less predictable and will require a more agile mode of management. Figure 2 suggests one generic way in which supply chain strategies may be devised for the predictable $20 \%$ and the more volatile $80 \%$ of products. 


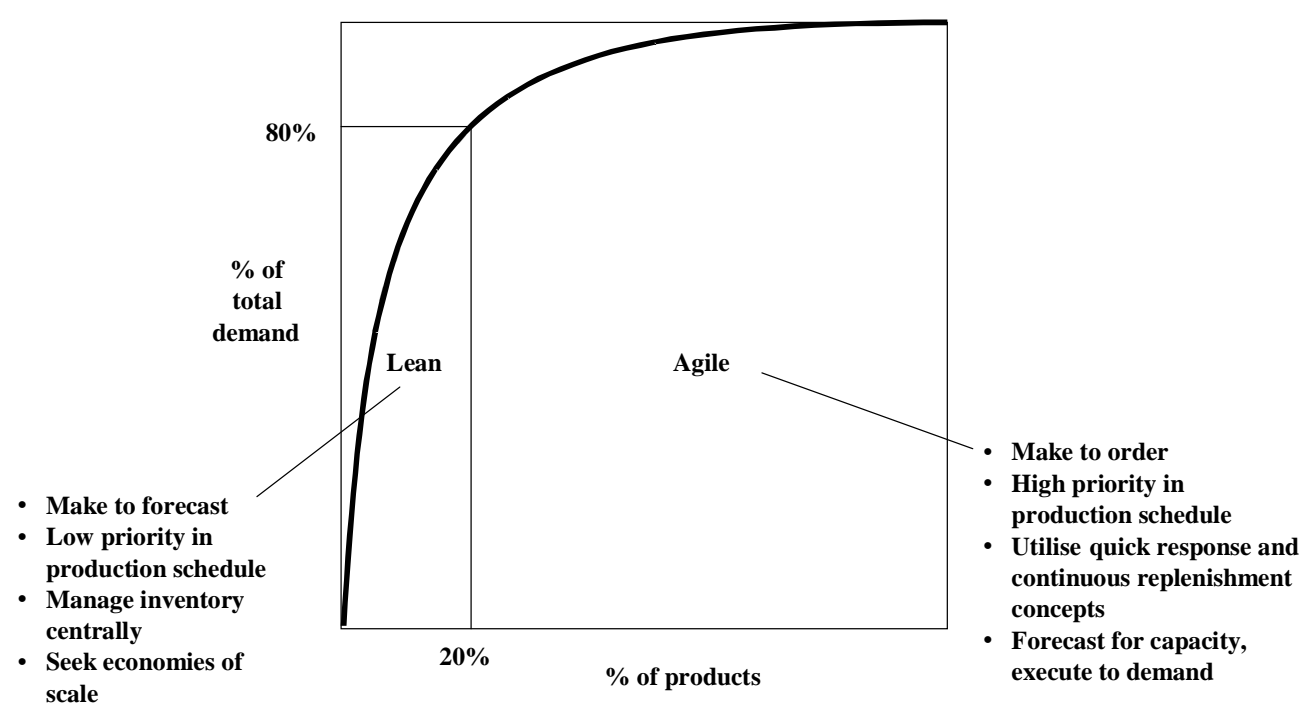

Figure 2 - The pareto distribution

\section{The De-coupling Point Approach}

A further marrying of the lean and agile paradigms can be achieved through the creation of a 'de-coupling point' using what may be termed strategic inventory. Here the idea is to hold inventory in some generic or modular form and only complete the final assembly or configuration when the precise customer requirement is known. An example is the customised PC (Christopher and Towill, 2000). This concept of 'postponement' is now increasingly widely employed by organisations in a range of industries (van Hoek, 1998). As shown in Figure 3, by utilising the concept of postponement, companies may utilise lean methods up to the de-coupling point and agile methods beyond it. Companies such as Hewlett Packard have successfully employed such strategies to enable products to be localised much closer in time to actual demand (Feitzinger and Lee, 1997). However, as Pagh and Cooper (1998) have pointed out, satisfying customer demand may require particular combinations of postponed manufacture and postponed logistics

A parallel concept to the 'material' de-coupling point described above is that of the 'information' de-coupling point (Mason Jones and Towill, 1999). This represents the furthest point upstream to which information on 'real' demand flows i.e. information which has not been distorted by inventory policies such as re-order points and re-order 
quantities. The ability to base replenishment decisions on real demand clearly contributes to supply chain agility.

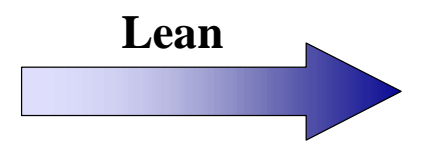

- Forecast at generic level

- Economic batch quantities

- Maximise efficiencies
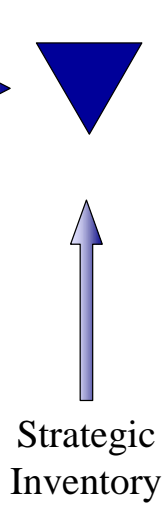

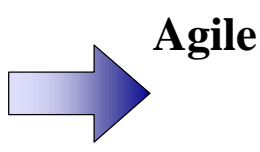

- Demand driven

- Localised Configuration

- Maximise effectiveness

\section{Figure 3 - The decoupling point}

\section{Separation of "Base" and "Surge" Demands}

Other hybrid strategies that have been employed with success are based upon separating demand patterns into 'base' and 'surge' elements (Gattorna and Walters, 1996). Figure 4 highlights this distinction together with one possible level scheduling solution where capacity demands are smoothed by intelligent switching of 'base' production. Base demand can be forecast on the basis of past history whereby surge demand typically cannot. Base demand can be met through classic lean procedures to achieve economies of scale whereas surge demand is provided for through more flexible, and probably higher cost, processes. Strategies such as these are increasingly being employed in the fashion industry where the base demand can be sourced in low cost countries and the surge demand 'topped up' locally nearer to the market. Even though the unit cost of manufacture in local markets will be higher than sourcing in low cost locations, the supply chain advantage can be considerable. Alternatively, arrangements can be made for dealing with both "base" and "surge" demands either by separation in space (via separate production lines) or in time (by using slack periods to produce base stock). This contrasts with the lean concept of 'level scheduling'. 


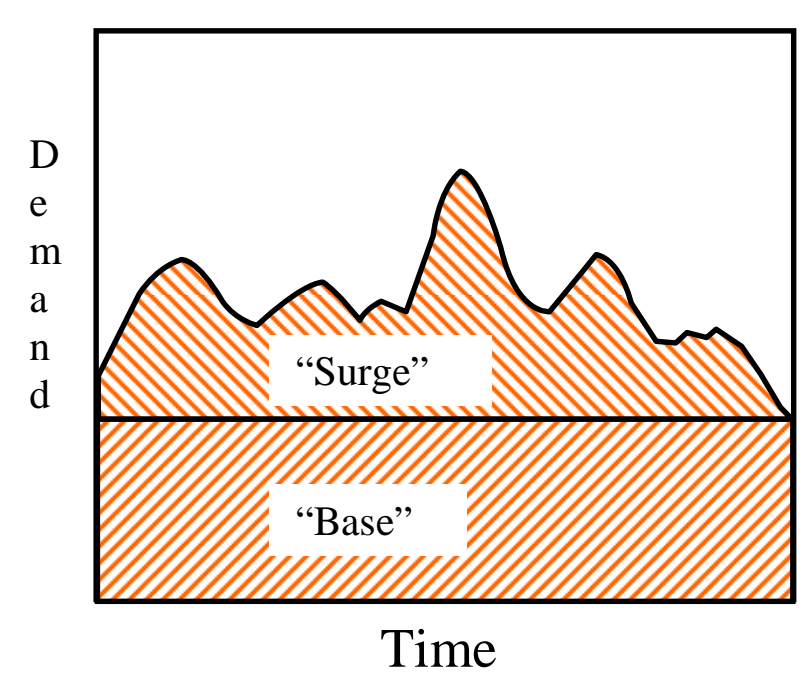

(a) Total

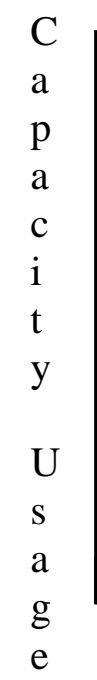

e

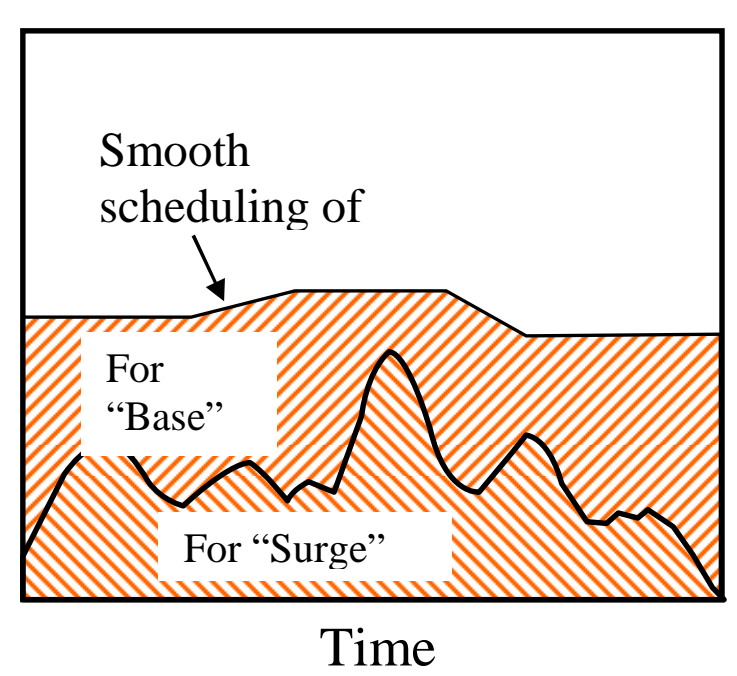

(b) Level Scheduling

Figure 4 - Responding to Combinations of 'Base' and 'Surge' Demands

Well documented companies employing such strategies include Zara (Christopher, 1998), Benetton (Zuccaro, 1998), and National Bicycle (Fisher et. al, 1994). What is particularly important is to relate the strategy throughout the whole supply chain to the needs of the end customer in terms of both affordability and availability.

Whilst these three strategies are complementary rather than mutually exclusive, it is likely that each may work better in certain conditions. A suggested set of appropriate conditions for the application of the three hybrid strategies is presented in Table III below :- 


\section{Appropriate market conditions and}

\section{Hybrid strategies}

operating environment

High levels of variety; demand is non-

proportionate across the range.

volume lines, agile methods for the slow movers.

De-coupling point The aim is to be lean up to the de-coupling point and agile beyond it.

\section{Surge/base demand separation}

Managing the forecastable element of demand using lean principles; using agile principles for the less predictable element.
Possibility of modular production or intermediate inventory; delayed final configuration or distribution.

Where base level of demand can confidently be predicted from past experience and where local manufacturing, small batch capacity is available.

\section{Table III}

\section{A Contingency Approach to Supply Chain Strategy Choice}

The three lean/agile hybrid strategies described above confirm that the real focus of supply chain re-engineering should be on seeking ways in which the appropriate combination of lean and agile strategies can be achieved. Our proposed Integrated Model described below provides the essential infrastructure.

\section{An Integrated Approach to Supply Chain Design.}

Our contention is that lean methodologies can be a powerful contributor to the creation of agile enterprises. In particular where product ranges can be separated according to volume and variability and/or where the de-coupling concept can be applied, a real opportunity exists for employing hybrid lean/agile strategies. There is also one important sense in which lean precedes agile, and which has been advanced 
by Victor and Boynton (1998) in the context of moving towards mass customisation. This is because real and effective change requires the mapping and understanding of all the relevant business processes. Thus, in an industrial engineering scenario the lean knowledge base is there to be exploited in enabling further performance improvements including building in agility (Childerhouse et al, 2000).

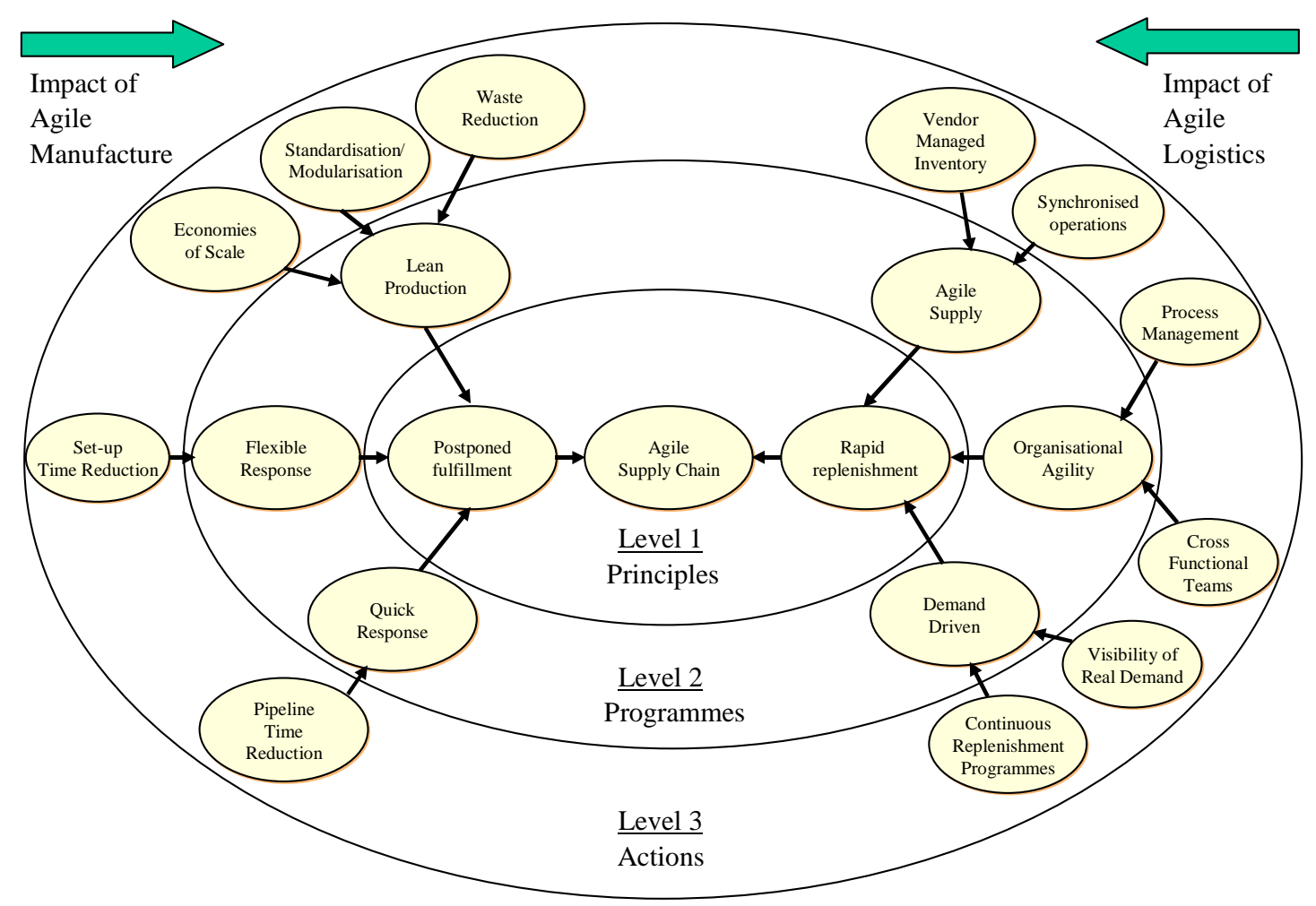

\section{Figure 5 : An Integrated Model for Enabling the Agile Supply Chain}

Figure 5 suggests a three level framework summarising our view of the agile supply chain. The concept of such a framework was first advocated by Werr et al. (1997). We have found it extremely useful in bringing together the various strands which contribute to the agile enterprise. In this integrative model, Level 1 represents the key principles that underpin the agile supply chain; rapid replenishment; and postponed fulfilment. Level 2 identifies the individual programmes such as lean production, organisational agility, and quick response which must be implemented in order for the Level 1 principles to be achieved. Level 3 specifies individual actions to be taken to support Level 2 programmes, for example, time compression, information enrichment, and waste elimination. Not all the characteristics shown in Figure 5 may be necessary in any one specific market/manufacturing context, but it is likely that the 
agile supply chain will embody many of these elements. What is certain is that much of the conventional wisdom concerning manufacturing strategy, supplier relations and distribution will have to be challenged if real agility is to be achieved from within the supply chain.

Rapid replenishment, for example, requires agile suppliers, organisational agility, and a demand driven supply chain (Lowson et.al. 1999). Similarly, postponed fulfilment enables the adoption of lean production principles up to the de-coupling point supported by agile capabilities beyond that point (Harrison et. al.1999). Nor must the cultural side be forgotten, since it may be the single biggest barrier to effective change. For example, in moving towards an agile structure in one company in the pharmaceuticals sector, it was found that the anticipated IT problems did not arise. Instead, the real stumbling blocks were the difficulty of creating an understanding of the new system, and the creation of a customer focused culture $\sim$ in other words people problems (Belk and Steels, 1998). Such reasons could also help explain why successful industrial implementation of quick response programmes is more patchy than expected, (Kohzab, 2000). This is just supporting evidence for the view previously expressed by Andraski (1994) in commenting on the ineffectiveness of many real-world supply chains. He suggested that this is because $80 \%$ of problems that arise are due to people, not technology'.

Creating an agile supply clearly requires a number of significant changes to the status quo. Supply chain managers today need also to be change managers - not just managing change within the organisation, but managing change in the way that relationships between organisations are structured. The trend towards the creation of the 'virtual' organisation, whilst likely to help achieve agility (Preiss et.al., 1995), also requires a high level of co-ordination and management. One way to achieve this coordination is to make use of a 'pipeline integrator' or, as they have sometimes been termed, a Fourth Party Logistics Service provider (4PL). These organisations make use of their expertise and knowledge of managing global supply chains to ensure that even in complex networks a more agile response can be achieved. An example of one company that is taking up this role on behalf of global clients is the Hong Kong based company $\mathrm{Li}$ and Fung (Magretta, 1995). Li and Fung were originally a trading company sourcing and distributing products on behalf of their principals. Over the 
years they have developed specific expertise and skills that enable them to manage and co-ordinate supply chains. For example, Li and Fung, on behalf of the US retailers, the Limited, will order un-dyed yarn from the yarn supplier, book weaving and dying capacity at fabric manufacturers' facilities and manufacturing capacity at the garment factories; all in advance of the actual requirement being known. As the Limited gets a clearer view of what the requirement is for actual styles, colours and sizes then $\mathrm{Li}$ and Fung will issue precise orders and manage the entire supply chain. In the words of the Chairman, Victor Fung :-

"It would be easier to let the factories worry about securing their own fabric and trim. But then the order would take three months, not five weeks. So to shrink the delivery cycle, I go upstream to organise production. And the shorter production time lets the retailer hold off before having to commit to fashion trend. It's all about flexibility, response time, small production runs, small minimum order quantities, and the ability to shift direction as the trends move”. (Magretta, 1995).

\section{Conclusion}

It is becoming increasingly apparent that competitive advantage derives from the combined capabilities of the network of linked organisations that today we call "the supply chain'. This is a fundamental shift in the traditionally held view of a business model based upon a single firm. It has also become apparent that markets today are increasingly volatile and hence less predictable and so the need for a more agile response has grown.

Putting these two ideas together leads us to the conclusion that a pre-requisite for success in these markets will be an agile supply chain.

What we have proposed in this paper is a framework for agility that is contingent upon the context in which the business operates. Thus we have sought to bring together the lean and agile philosophies to highlight the differences in their approach but also to show how they might be combined for greater effect. Increasingly, managers need to 
understand how market conditions and the wider operating environment will demand not a single off-the-shelf solution, but hybrid strategies which are context specific.

\section{References}

Aitken, J., (2000) “Agility and Leanness - A Successful and Complimentary

Partnership in the Lighting Industry", Proc. LRN 2000 Conference, pp 1-7.

Andraski, J.C., (1994), "Foundations for a Successful Continuous Replenishment Programme, International Journal of Logistics Management', Vol 5, No. 1, pp 1-8

Belk, K. and Steels, W., (1998), " Case study - APS Berk - from arbitration to agility ", Logistics Information Management, Vol. 11, No. 2, pp 128-133

Childerhouse, P., Disney, S. and Towill, D.R., (2000), "Speeding up the Progress Curve towards Effective Supply Chain Management", International Journal of Supply Chain Management', Vol 5, No. 3, pp 176-186.

Christopher, M., (1992), Logistics \& Supply Chain Management, Pitmans, London, UK.

Christopher, M., (2000), “The Agile Supply Chain: Competing in Volatile Markets”, Ind. Mark. Man., Vol 29, No. 1, pp 37-44.

Christopher, M., (1998), “Logistics \& Supply Chain Management”, London, Pitmans.

Christopher, M. and Towill, D.R., (2000), "Supply Chain Migration from Lean and Functional to Agile and Customised", Int. Jnl. Sup. Ch. Man, 5(4), pp 206-213.

Feitzinger E. and Lee, H.L. (1997), "Mass Customisation at Hewlett Packard - The Power of Postponement", Havard Business Review, Jan-Feb, pp 116.121.

Fisher, M., (1997), “What is the Right Supply Chain for your Product?”, Harvard Business Review, March/April.

Fisher, M., Obermeyer, W., Hammond, J. and Raman, A., (1994), "Accurate Response: the Key to Profiting from Quick Response”, Bobbin, Feb. pp 48-63.

Gattorna, J.L. and Walters, D.W., (1996), "Managing the Supply Chain - a Strategic Perspective”, MacMillan, London.

Harrison, A., Christopher, M. and van Hoek, R., (1999), "Creating the Agile Supply Chain” School of Management Working Paper, Cranfield University. Hill, T. (1993), Manufacturing Strategy : Text and Cases, Second Edition, MacMillan Press, London.

Johansson, H.J., McHugh, P., Pendlebury, A.J. and Wheeler, W.A., (1993) 
Business Process Reengineering: Breakpoint Strategies for Market Dominance, John Wiley and Sons, Chichester, UK

Koch, R., (1997), The 80/20 Principle; the Secret of Achieving More with Less, Nicholas Brealey, London.

Kotzab, H., (2000), Managing the Fast Moving Goods Supply Chain - Does Efficient Customer Response Matter?", Proceedings of the Logistics Research Network Conference, Cardiff University, Wales, pp 336-342

Lowson, R., King, R. and Hunter, A., (1999), Quick Response : Managing the Supply Chain to Meet Customer Demand, John Wiley \& Sons, Chichester

Magretta, J., "Fast, global and entrepreneurial : Supply Chain Management Hong Kong Style", Harvard Business Review, September - October

Mason-Jones, R., Naylor, B., and Towill D.R., (1999), "Lean, Agile, or LeagileMatching Your Supply chain to the Marketplace", Proc. $15^{\text {th }}$ Int. Conf. Prod. Res., Limerick, pp 593-596.

Mason-Jones, R., Naylor, J.B., and Towill, D. (2000), "Engineering the Leagile Supply Chain", to be published, Int. Jnl. Agile Man. Systems.

Mason-Jones, R. and Towill, D., (1999), "Using the Information Decoupling Point to Improve Supply Chain Performance”, International Journal of Logistics Management, Vol. 10, No. 2, pp 13-26

McHugh, P., Merli, G. and Wheeler III, W.A., (1995), “Beyond Business Process Re-Engineering - Towards the Holonic Enterprise”, John Wiley and Sons, NY.

Nagel, R. and Dove, R., (1991), $21^{\text {st }}$ Century Manufacturing Enterprise Strategy, Incocca Institute, Leigh University.

Naylor, J.B., Naim, M.M. and Berry, D., (1999) “Leagility: Interfacing the Lean and Agile Manufacturing Paradigm in the Total Supply Chain", International Journal of Production Economics, Vol 62, pp 107-118.

Ohno, T., (1998), The Toyota Production System; Beyond Large Scale Production, Portland, Oregon : Productivity Press, 1988

Pagh, J.D. and Cooper, M.L., (1998), "Supply Chain Postponement and Speculation Strategy: How to Choose the Right Strategy”, Jnl; Bus. Log., 19(2), pp 13-33.

Preiss, K., Goldman, S.L., \& Nagel, R.N., (1995), Agile Competitiors and Virtual Organizations, New York, Van Nostrand Reinhold

Shewchuck, P., (1998), “Agile Manufacturing : One Size Does Not Fit All”, Proc. Int. Conf. On Manufacturing Value Chains". Troon, pp 143-150. 
Towill, D.R., (1996), “Time Compression and Supply Chain Management - a

Guided Tour", Supply Chain Management, Vol 1, No. 1, pp 15-27.

Towill, D.R., Childerhouse, P. and Disney, S.M., (2000) "Speeding Up the Progress

Curve Towards Effective Supply Chain Management”, Int. Jnl. Sup. Ch. Man, 5 (43), pp 122-130.

van Hoek, R., (1998), "Reconfiguring the Supply Chain to Implement Postponed Manufacturing", International Journal of Logistics Management, Vol. 9, No. 1.

Victor, B. and Boynton, A.C. (1998), Invented Here : A Practical Guide to Transforming Work, Harvard Business School Press, Cambridge, Mass.

Warnecke, H.J. and Huser, M., (1995), “Lean Production”, Int. Jnl. Prod. Econ., 41, pp 37-43.

Werr, A., Stjernberg, T. and Docherty, P., (1997), "The Functions of Methods of Change in Management Consultancy", Journal of Organisational Management Change, Vol. 10,No. 4, pp 288-307

Womack, J., Jones D. \& Roos, D., (1990), “The Machine that Changed the World”, New York : Macmillan, 1990

Womack, J.P. and Jones, D.T., (1996) "Lean Thinking", Simon and Schuster, NY, 1996.

Zuccaro, B., (1998), Keynote Address, EUROMA Conference on Managing Operations Networks, Venice. 